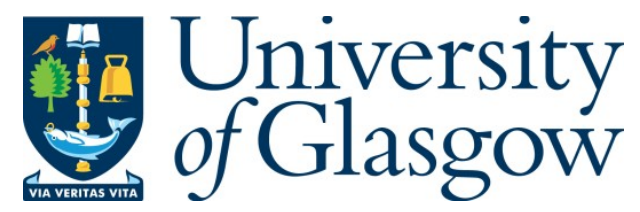

Chiong, C. and Dimmock, C. (2020) Building trust: how low-income parents navigate neoliberalism in Singapore's education system. Comparative Education, 56(3), pp. 394408.

(doi: $10.1080 / 03050068.2020 .1724487$ )

This is the Author Accepted Manuscript.

There may be differences between this version and the published version. You are advised to consult the publisher's version if you wish to cite from it.

https://eprints.gla.ac.uk/209415/

Deposited on: 7 February 2020

Enlighten - Research publications by members of the University of Glasgow http://eprints.gla.ac.uk 


\section{Building Trust: How low-income parents navigate neoliberalism in Singapore's education}

system

Charleen Chiong ${ }^{\mathrm{a} *}$ and Clive Dimmock ${ }^{\mathrm{b}}$

${ }^{a}$ Faculty of Education, University of Cambridge, Cambridge, United Kingdom; ${ }^{b}$ School of Education, University of Glasgow, Glasgow, United Kingdom

E-mail for *corresponding author: cnc30@cam.ac.uk

Twitter for *corresponding author: @CNCharleen

Charleen Chiong (cnc30@cam.ac.uk) is a doctoral candidate at the Faculty of Education, University of Cambridge. Her research, funded by a Cambridge International Scholarship, explores how socioeconomically low-income families navigate the education policy landscape in Singapore.

Clive Dimmock (clive.dimmock@glasgow.ac.uk) is Professor of Leadership and Professional Learning in the School of Education, University of Glasgow. He is also Senior Research Fellow at the Asia Pacific Centre for Leadership and Change, Education University, Hong Kong. His research has concentrated on cross-cultural comparative leadership and schooling in Asian contexts, especially Singapore, Hong Kong and Vietnam. 


\section{Building Trust: How low-income parents navigate neoliberalism in Singapore's education system}

Singapore is described as a hybrid neoliberal-developmental state. While politicians have, since the city-state's independence, exercised 'strong' ideological leadership over Singapore's economy and society, including education - there are simultaneously aspects of 'neoliberal' logics in Singapore's education system: extensive school choice and streaming, academic competition and the self-responsibilising meritocratic ethos. Literature on the nature and effects of neoliberalism typically depicts rising inequalities and families' growing anxieties, due to competition and self-responsibilisation. Drawing on in-depth interviews, this article explores how a group of low-income Malay parents navigate two aspects of institutionalised neoliberalism: (1) responsibilisation of young people within a meritocratic regime, (2) responsibilisation of parents as stakeholders in an increasingly complex education landscape. We find that while families internalise responsibilisation - profound trust in the state remains. Empirical particularities are drawn upon to understand how a socio-politically-constituted 'architecture of trust' between state and low-income parents is built, and its implications on families' lives.

Keywords: parents, neoliberalism, trust, responsibilisation, education policy, inequality, Singapore

Word count (including references): 6,984

\section{Introduction}

This paper examines how low-income Singaporean parents endeavour to support their children in negotiating a successful future within the hyper-competitive Singapore education system, characterised by various neoliberal institutional practices. To understand this, we draw on the conceptual apparatus of an 'architecture of trust'. We note that 'trust', while sometimes implied or theorised as the underlying roots of social behaviour and interactions (Misztal 1996; Blind 2007), is rarely foregrounded in studies of parents' pedagogic practices and beliefs. Yet, our analysis of interview data suggests that conceptualising parents' pedagogic work in terms of 'trust' - specifically, 
'political trust' - is important, particularly in the 'strong' Singaporean state (L. Lim 2016) which actively mediates everyday life in Singapore.

Political trust - or trust in government institutions - is not entirely an a priori virtue, depending on whether it is justified or not (Field 2008). Nonetheless, it is generally theorised as beneficial in myriad ways: it is vital to regime stability and to citizens' support of policy reform (Wong, Wan \& Hsiao, 2011); it also lubricates social life, facilitating both the government's daily functioning in providing services, and its ability to act decisively in moments of crisis (Ho 2018). However, 'neoliberal' institutional practices have been linked to the weakening of political trust and other forms of interpersonal trust. 'Neoliberal' practices are understood as creating feelings of distance, disenfranchisement and distrust, particularly between state institutions and ethnic minority, lowincome groups (Güemes 2017; Ule, Živoder, and du Bois-Reymond 2015), who are especially vulnerable to the inequalities generated through neoliberal policy reform.

'Neoliberalism' is a term that is often used, yet often unclearly demarcated. In this paper, we define it on two levels (Flew, 2014). At the 'ideas' level, it is the entrenchment of the 'mercantile society' (Foucault 1979:194) where knowledges and practices are legitimated within a 'pragmatics of optimization [sic]' (Ball, 2012:33). At the 'institutions' level, neoliberal governing prioritises the market form, commodification, capital accumulation, skills and profits over ideals (Shamir, 2008; Ball 2012) and other social goals (Flew 2014) - which generally leads to detrimental equity effects. While this delineates the term's conceptual parameters, we agree with Ong (2007:3) that 'neoliberalism' is a 'mobile technology'; thus, contexts such as Singapore offer 'a rich empirical context for illuminating how neoliberal logic is inveigled into constellations of authoritarian politics and cultural ethics.'

Yet, insufficient empirical research has explored the relationship between neoliberal education policies and families' pedagogic practices, particularly in Asian socio-political and educational contexts. Research on the expansion of school choice in Australia points to feelings of anxiety, powerlessness and frustration with institutions, rather than trust (e.g. Campbell, Proctor, \& Sherington, 2009). The responsibilisation of parents and increasing anxiety related to 'intensive' parenting in response to neoliberal imperatives, has been described in largely European-American contexts (e.g. Vincent \& Maxwell, 2016). Moreover, research suggests the relation between living within a neoliberal political-economic regime and families' pedagogic practices is likely classed and raced. For instance, research often portrays relations between low-income, ethnic minority families and schools as strained (Lareau, 2003; Vincent \& Ball, 2007; Watkins \& Noble, 2013), due to home-school mismatches in cultural values, role expectations, communication styles and child-rearing approaches. However, little is known about low-income families' pedagogic work, and its relations with neoliberalism and trust, particularly in Asia. 
Against this backdrop, the Singapore context is an apposite site for inquiry. The Republic of Singapore is a city-state of 5.6 million people (75\% 'Chinese', 13\% 'Malay-Muslim', 8\% 'Indian'), that has transitioned rapidly from a backwater fishing village at the time of independence in 1965, to a bustling cosmopolitan city. It is a city-state widely viewed as a 'success' story, with a worldrenowned education system (Deng and Gopinathan 2016; Dimmock and Tan 2015) and high levels of political trust, compared to other states in Asia (Wong et al, 2011; Quah, 2010) and globally (Edelman 2018).

In this paper, we explore two instances of institutionalised neoliberalism, from the perspectives of low-income parents in Singapore: (1) responsibilisation of young people within a competitive, meritocratic regime, (2) responsibilisation of parents in an increasingly diverse education landscape. We then reflect on the co-construction of an 'architecture of trust' between state, schools and families - which enables, and makes plausible the devolution of responsibility to parents and children.

\section{Raising Children in 'Neoliberal-Developmental' Singapore}

We begin by outlining features of Singapore's socio-political and educational context that are pertinent in understanding families' pedagogic practices and beliefs. Singapore is described as a hybrid 'neoliberal-developmental' state (Liow 2011:241), combining governing logics that both invites dependence on itself ('developmental' logics), and devolves responsibility to individuals and families ('neoliberal' logics).

On the one hand, the 'developmental' Singapore state has long exercised ideological leadership - even 'soft authoritarianism' - over economy and society, including its education system (Gopinathan 2007). The 'developmental' state seeks political legitimacy through active interventions to boost economic performance (ibid). Historically, according to Singaporean politicians, this interventionist approach was necessary to ensure social stability and optimal human capital development under conditions of 'crisis' and vulnerability. Furthermore, the Singapore state espouses a 'pastoral' function to take care of its citizens, unlike the chiefly 'procedural' function of politically liberal states (Leonel Lim and Apple 2016). For instance, there exists a highly-developed, 'social democratic' programme of largely state-owned, well-resourced, highly-subsidised public education and housing (Chua 2017:7).

Furthermore, while Singapore's Ministry of Education (MOE) has over time devolved some autonomy to schools (particularly to high-performing, prestigious schools) - it closely oversees many aspects of its largely-centralised education system, including the prescribing of curricula, textbook use, administration of national examinations, the hiring and firing of teachers and their professional 
development and training (centralised in the MOE's National Institute of Education) (Deng and Gopinathan 2016). The vast majority of Singaporean students attend schools that, though diversified, remain closely regulated by the MOE.

On the other hand, market logics are clear in Singaporean governance; politicians from the People's Action Party (hereon, PAP) - Singapore's ruling party from independence until the presentday - have long advanced a forceful anti-welfarist ideology (Chua 2017; Teo 2013). The PAP explicitly describes Singapore as a 'meritocracy'; this self-responsibilising, individualistic ethos is underlaid by the assumption that anyone with talent and effort can achieve educational and life success. Distancing itself from affirmative action policies adopted by Malaysia, 'meritocracy' was adopted as a fundamental organising principle of the Singapore state, since independence. 'Meritocracy' was framed as a fair, efficient way to allocate resources, to reward talented, hardworking individuals and protect against complacency and nepotism - and to select the most meritorious (in the Singapore context, academic results are the main arbiter of merit) to occupy high-ranking jobs for optimal political leadership and economic efficiency (Tan 2008).

Singaporean 'meritocracy' translates to a highly-diverse education system, characterised by a growing diversity of school types and extensive streaming (justified politically as catering to students' different abilities and interests) and high-stakes examinations. Following the Primary School Leaving Examinations, extensive streaming takes place - each stream has different curricula, and is associated with different educational and life outcomes (Anderson 2015). After Secondary school, students can enroll in Junior College (the academically most competitive post-Secondary institution), or one of the two major vocational institutions: Polytechnic, or the Institute of Technical Education (the least academically competitive). Overall, principles of competition, diversification, human capital development, and individual and familial responsibility for success, pervade Singapore's education system.

In light of these neoliberal institutional practices, it is unsurprising that class and ethnic-based social and educational inequalities exist ( $\mathrm{Ng}, 2014)$. For instance, a disproportionately large group of upper-middle-class Chinese students obtain prestigious scholarships and attend elite schools (Lim, 2013). Moreover, emerging research on middle-class parenting problematises the rise in academic competition, and 'kiasuism' (a Singaporean colloquialism referring to the intense anxiety and fear of losing out) and 'tiger' parenting (e.g. Bach and Christensen, 2017). Commentators have described an effective shift from 'meritocracy' to 'parentocracy' (Ong 2014), as middle and upper-class parents cope with academic competition through investing in private tuition and extracurricular activities, and extensive strategising in school admissions enrollment. School choice is constrained by catchment areas, where students are likelier to gain entry to schools within a specific radius of where they live. 
Consequently, many wealthy parents have bought homes near to good schools (Koh, 2014), producing "wealthy enclaves" (Gee, 2012:4-5). Furthermore, large-scale quantitative analysis suggests a persistent gap between the Malay minority group and their Chinese counterparts, not only in earnings (Moore 2000), but in educational attainment and opportunities (Barr and Skrbis 2008; Senin and Ng 2012).

Thus, families' pedagogic work takes place within a socio-political context comprising governing logics that both invite dependence on the state, yet devolve responsibility to individuals and families. Within this complex context, the concept of political trust helps us understand families' pedagogic work.

\section{Political Trust, the State-Citizen Compact and Neoliberal Fractures}

Recent growth in social scientific literature on 'trust' has occurred, out of the recognition that trust levels are generally declining in European-American contexts (Levi and Stoker 2000). Surveys (e.g. Edelman, 2018) and theoretical analyses (e.g. Misztal 1996), attribute such decline partly to trends of individualisation and responsibilisation that are connected to neoliberalism and neoliberal policy reform that fragment and atomise (Barbalet 2019).

This study explores how political trust exists, rather than becomes negated by, neoliberal selfresponsibilisation. Broadly, political trust refers to citizens' evaluative orientation in appraising the government and its institutions as responsive, and able and willing to do what is right, even in the absence of constant monitoring (Hetherington, 1998; Levi and Stoker, 2000). This study, in line with relevant literature, views 'political trust' as follows. Firstly, political trust operates through dispositions, beliefs and affects experienced by the trust-giver (Misztal, 1996) and thus has an individual dimension, even if the 'recipient' of trust is an abstract, collective entity, such as the state. In Singapore, the 'recipient' of political trust is the state (specifically, the PAP, which has been the only political party to rule Singapore since independence) and state institutions (such as schools), although both tend to be conflated in interviewees' perspectives, in the 'strong' state of Singapore. Secondly, political trust always involves an element of risk-taking and vulnerability (Levi and Stoker 2000) - at its core is "something other than knowledge or uncertainty" (Barbalet, 2019:87).

Thirdly, political trust tends to be self-reinforcing - although ruptures of trust also commonly occur (and even when they do, relationships between state and citizens might still continue - for instance, due to fear of state reprisal) (Barbalet, 2019). Fourthly, political trust is not unconditional; perceptions of institutional performance is crucial in forming political trust. Institutional performance can be subdivided into economic performance (e.g. securing satisfactory standards of living) and 
political performance (e.g. the state's transparency, lack of corruption, and protection of human rights) (Mishler and Rose 2001; Levi and Stoker 2000). Furthermore, cultural values such as deference to authority, and socio-demographic variables (age, occupation, education level) can influence political trust by shaping perceptions of institutional performance (Mishler and Rose, 2001). Fifthly, political trust brings various benefits, but is not always desirable; some degree of mistrust is healthy in a wellfunctioning democracy (Field 2008). Hence, social capital and trust (including political trust) should be viewed as conceptually distinct (Field 2008). The former is conceptualised as bringing unequivocal benefits to individual and society, while the latter may or may not, depending on whether the trust is misplaced, built on 'cruel optimism' or unlikely fantasies of social mobility within 'compromised conditions of possibility' (such as an economy in austerity) (Berlant 2011:4).

A growing literature on political trust in authoritarian Asian states, such as China (Wang 2005; Tao et al. 2014), suggests that political trust tends to rise with economic growth and living standards. However, these authors also point to a likely decline in political trust as more educated, 'critical citizens' emerge who are more assertive and less deferential to authority (Wang 2005). In Singapore, state-citizen relations have followed a 'prosperity-loyalty' state-citizen compact (Gopinathan 2007), where the state provides the conditions for material flourishing (high-quality public infrastructure, steady economic growth, social stability and a low crime rate) in exchange for citizens' loyalty to the government and its ideals of a disciplined workforce (Gopinathan, 2007). While for decades the PAP has secured economic growth and upward social mobility, commentators suggest that the state-citizen compact has come under increasing pressure from the growing dissatisfaction of a more critical, assertive populace - over the increasing cost of living, slowing social mobility, immigration and the precarities of globalisation, and growing educational and job competition (Rodan 2016; Gopinathan 2012). Despite reaching a historic low in popularity in the General Elections of 2011, following the PAP's concerted efforts at social spending boosts, the results of the subsequent 2015 General Elections (Rodan 2016), and large-scale surveys (Edelman 2018), suggest that Singaporeans continue to exhibit high levels of trust in their government.

Singapore's 'prosperity-loyalty' compact may seem a limited, instrumental state-citizen relationship. However, richer ideological forces structure this compact - including neo-Confucianism, which Singapore's Chinese-majority political elite have drawn on from the city-state's early days (Chua 2017). According to Confucian ideology, deep morally-based exchanges of trust exist between those who rule and those who are ruled; 'trustworthiness' must be earned by the political elite, to secure the trust of the masses - after which, the state has a moral charge to take care of its citizens (L. Lim 2016). Such socio-political arrangements have implications for how both citizens and those in authority are to act in relation to one another. Political trust, then, has a 'thicker', moral texture to it in 
Singapore (compared to political-liberal conceptions of 'trust') - although the PAP is likely to draw on a mixture of both ideological traditions (Chua, 2017).

Overall, political trust, generated through cultural reasons and (perceptions of) institutional performance, appear to deeply structure the lived experience of the state-citizen compact in Singapore. However, what is the constitutive nature of these trust relations, and to what extent, and how, do these relations reconfigure families' pedagogic work? This question is suitably unpacked through empirical qualitative inquiry.

\section{Method}

This study draws on a subset of findings from a larger project. It focuses on in-depth, semi-structured interviews with parents (six mothers, three fathers) from low-income, Malay families. The aim of this small-scale study is not statistical generalisability, but to provide preliminary analytic insights into an under-researched area: how low-income families negotiate educational opportunities, within the Singaporean socio-political context. All parents in this study self-identified as 'Malay'. While we recognise that social class is racialised in complex ways in Singapore, we do not make generalisations in this paper concerning how participants' ethnic background relates to their narratives (further scholarship might foreground this). This is because firstly, the purpose of this paper is to sketch families' pedagogic work and the processes and challenges they identify as important; secondly, to avoid racial stereotyping; thirdly, social class divisions are described as more salient than racial divisions in Singapore (Teo 2018) - and seemed to be so, from families' interviews.

Interviews took place with participants' voluntary, informed consent and with promise of anonymity, and were typically conducted in participants' homes. While the aim was to interview both parents in each family, due to irregular working (shift) hours, divorce and linguistic barriers, this was not always possible. As there is no detailed mapping of 'social class' structure in Singapore, a conceptualisation of indicators of household economic disadvantage was constructed - derived from a combination of Tan's (2004) work on inequality in Singapore, Lareau's (2003) work on working and middle-class families in the U.S., and the Singapore Department of Statistics (2016) report:

1) Monthly household income per household member of SGD $\$ 1,100$ and below (bottom $20 \%$ of population)

2) Parental education - typically attainment of secondary school qualification at most

3) Parental occupation - typically either unemployed or working in the lowest-earning occupation categories in Singapore (Sales/Service Workers; Plant and Machine Operators/Assemblers; Cleaners, Labourers and Related workers) 
Furthermore, we focused on parents with children at the Secondary Four level in mainstream government schools (attended by the majority of Singaporean students), as young people in this group are at the cusp of making decisions about which post-Secondary institutions to attend. As such, Secondary Four is an apposite time to understand families' perceptions of the entanglement of opportunities and constraints in Singapore's education system. A local community organisation facilitated contact with families.

Semi-structured interviews allowed a balance between pre-prepared questions, and participants' expression of perspectives on their own terms. Two rounds of semi-structured interview (each lasting 60-120 minutes) were conducted with each parent. First-round interview questions invited parents to expand on their general imaginary and worldview concerning education and childrearing (e.g. 'what is the purpose of education?', 'who is most responsible for a child's success - the child, the parents or the school?'). Second-round questions focused specifically on the social and educational policies and services parents use, and the meanings they attach to these policies and services (e.g. 'What do you like/dislike about your child's school?', 'How often do you meet your child's teachers? What are those meetings like?'). The interviews were transcribed, coded and analysed thematically (Braun and Clarke 2006), drawing on an understanding of Singapore's socio-political and educational context, developed through speaking to academic and policy experts, and reading policy documents, speeches, news articles and academic literature. We have edited interview quotes lightly to help non-Southeast Asian readers understand these quotes.

\section{Discussion}

In understanding how parents endeavor to negotiate a successful future for their children, the notion of political trust co-existing with, rather than becoming negated by, neoliberal responsibilisation of children and parents - emerged as a key theme. To explore this, we discuss how parents negotiate two key instances of institutionalised neoliberalism: (1) responsibilisation of the child, (2) responsibilisation of parents within a complex, diverse education landscape. Through this, we elucidate reasons why responsibilisation might coexist with political trust - and then elaborate on these reasons as building-blocks of an 'architecture of trust'. The word 'architecture' highlights the socially constructed nature of 'trust' in this study, and thus does not preclude the notion that 'trust' may be a product of state-craft. Yet, to read parents' expressions of political trust wholly as a product of state manipulation is to see parents less as autonomous agents and more as dupes, and to advance an overly 
pessimistic view of Singaporean parents' agency. As such, it is more valuable to delve deeply into the empirical elements comprising the construction of political trust.

\section{Reproducing Meritocracy: Responsibilising the Child}

A key form of neoliberal institutional practice in Singapore is the responsibilisation of families and individuals. This responsibilisation is inculcated through a highly diverse, high-stakes education system; Singapore's '[diversity] metaphor is deeply connected to policy construction and the legitimation of neo-liberalism and individual/social responsibility' (Talib and Fitzgerald, 2015:449). Responsibilisation is a technique of government that constructs in its citizenry a sense of 'moral agency', a 'reflexive subjectivity' and certain dispositions and actions - in order to partake in selfgovernment and authority, and bear the consequences for one's actions (Shamir, 2008:4).

All interviewed parents seemed to internalise meritocratic responsibilisation, holding young people to be the most crucial actors in achieving educational (and thus, life) success. 'The government', 'schools' and 'parents' were typically depicted as playing subsidiary roles in achieving successful outcomes. One mother, Izzati, remarked: '[E]ven though the school gives them [everything] - if they don't try to work it out in their heart to want to study, they won't get it. There won't be any changes in their life, actually.' Many parents perceived that education stakeholders (parents, school, society) play a facilitative role, while young people themselves are most responsible. Parents often discussed their children's heavy workload and insufficient time for rest, yet nevertheless ultimately seemed to accept that the child was most responsible for their own success (and conversely, to be blamed if they failed). Furthermore, crucially, it seemed that parents' negative emotions regarding workload and stress, and acceptance of responsibilisation, were mediated by a respect for, and trust in, the competence of the Singapore state that enabled this responsibilisation.

Parents' reasons for trust can be placed in two categories: (1) generous, high-quality material provision of education-related services, (2) belief in the efficacy of the Singaporean education system and of Singacccporean meritocracy. Firstly, despite espousing an 'anti-welfarist' (Teo 2013:387) ideology, the Singapore government invests heavily in the widespread provision of quality education, including vocational training, as it does for other collective-consumption goods and services, such as public transport and housing (Chua 2017). Parents cited the speed of the government's processing of requests for financial help for anything education-related, such as school books and shoes (relative to anything non-education-related), because they understood education to be a national priority in Singapore. Interviewed parents largely agreed that the state had provided the conditions for prosperity 
(their part to play, in the state-citizen compact), particularly through providing the means for highquality, highly-subsidised schooling.

Furthermore, parents were convinced of the quality of Singaporean public education, reinforced by its international reputation. Through what we call ideational-comparative reasoning, parents compared education in Singapore with that of countries where many of their extended family reside (generally, Malaysia and Indonesia). Singapore's political leaders had, in their view, effectively consolidated the education system, re-moulding it to be highly professional and effective. They felt their views were legitimised through the results of international ranking tests, such as PISA, that positioned Singapore as the 'top' and 'best' in the world - narratives of global recognition that parents read or heard about via (largely state-regulated) media channels in Singapore.

Thus, overall, in a context where there is a strong values orientation towards the importance of academic achievement, typical of majority-Chinese and Confucian societies (Tan 2018) - education (defined by parents mainly as basic skills of literacy and numeracy, and qualifications) was seen as a protective shield against life's perils. Moreover, it is precisely because of the state's generous provision of education and education-related activities (through government schools and free or highlysubsidised tuition through welfare organisations) that parents deeply trusted the state. The state, in parents' views, has already 'done its best'; it is now up to the child to work hard, and it is also the child's fault if they fail.

Secondly, due to the state's careful, interventionist management of the 'tight coupling' between education and economy (Dimmock and Tan 2015), parents could draw on anecdotal evidence of the successful operation of the meritocratic mechanism in the lives of friends and extended family members, who achieved high academic qualifications and subsequently succeeded in attaining wellpaid jobs. One mother, Naadia, stated:

Whenever we go out, I tell [my son], I'm not trying to say the other people are so good. [But] I say, 'You see baby -' we call him 'baby' [...] cos he's the younger one so he's like a baby to us. So I say, 'Baby, you see... I get to know from my cousin the son pass his Poly' [...] I say: 'You see he pass his Poly, he go NS [National Service], the moment he finish NS, he go university and now he can find a better job. Don't you like to be like him?

Parents evidenced deeply-rooted confidence in the teleological, inevitable linearity of meritocratic logic (i.e. get-good-grades so you can get-good-jobs). One father, Khairul, noted that getting good grades 'can help you become minister, can become doctor, can become all these, you need to study also. You don't [study], you cannot go anywhere.'

Thus, the coalescence of neoliberal and developmental state logics likely structure pedagogic beliefs whereby parents both trust the state and believe their children should shoulder individual 
responsibility for their futures, even if they feel the overall academic stressfulness of the system should be reduced. Overall, in light of the material and ideational-comparative reasons above, deep trust coexists with (rather than becomes negated by) self-responsibilisation, in the 'strong' state of Singapore. Notwithstanding parents' confidence in the Singapore state, there were glimpses of disillusionment with the heavy workload children shouldered. Most parents accepted the harshness of meritocracy with a stoic pragmatism, seeing this as a way of life in Singapore, where they are at least provided with a roof overhead and a globally respected education system, which they trusted would secure their children a better future.

\section{Parents as Stakeholders: Responsibilising Parents}

Increasingly, convergent with broader shifts towards the responsibilisation of parents (Forsey, Davies and Walford, 2008), the MOE describes parents as 'stakeholders' or 'partners' in helping their children negotiate Singaporean education (Khong and Ng 2005). For instance, schools expect parents to supervise their children's homework, and help them with school selection. Within an increasingly complex education landscape, how do low-income parents in Singapore navigate their roles as 'stakeholders' in education?

Generally, parents hold the family as responsible for educational and life success, in a context of perceived government competence and its normative orientation towards fairness and doing good. For instance, one mother, Dania, cited the 'low self-esteem' of parents, as the reason for why 'lowincome families' cannot rise beyond their circumstances:

Some of them, they are not very confident, or they are not brave enough to come out and step up, you see? So for me, I know that the government is doing their best to get every child the same education [...] It's just that the parents have to step up, they cannot just keep quiet and let their children suffer.

While some parents seemed self-conscious over their limitations in providing any 'specific' help with schoolwork and decision-making (particularly as, they felt, they were 'uneducated'), all parents took seriously their role as stakeholders in their child's education. Parents saw their role as 'getting behind' their children to 'push them' to attain the highest academic qualifications they can attain, as one mother, Juriffah, described. 'Getting behind' involved advising, encouraging, filling in complicated forms to apply for state subsidies, monitoring their children's academic progress, even checking school bags to ensure children had completed homework, and above all, nagging their children to 'study hard'. They played by the rules of the meritocratic game, in the belief that such an approach would help their children acquire future success. 
Parents' belief in the normative orientation of the state towards doing good, is remarkable particularly in Singapore, where the intensification of parenting (and the stratified nature of this intensification) is increasingly apparent. At least two parents described having no concrete 'strategy' for their child's academic success. Most interviewed parents did not seem fully aware of, and were somewhat nonchalant about, the spectrum of 'parentocratic' strategies wealthier parents deploy. The two parents who were aware, recognised that while they would like to send their children for private tuition and enrichment classes, they could not compete financially with their wealthier counterparts. However, these parents also simultaneously felt that 'extra' programmes were not particularly desirable, given schooling hours often lasted until late afternoon and early evening, usually due to 'remedial classes' (after-school classes geared towards examination preparation). After remedial classes, young people often attended tuition run by state-initiated local community organisations for additional educational support. Parents were conscious of their children's physical and mental limitations; they felt that between formal schooling and tuition (which often ran from 7-9pm on certain weekdays, and on Saturday mornings), their children were adequately supported. 'Studying hard', within limits, they felt, was sufficient for life success. All were contented with their level of participation in their children's educational lives. As such, while wealthy parents are described as holding increasing power in 'parentocratic' Singapore, most families interviewed in this study did not seem aware or very bothered by it, placing trust in the dependability of the 'strong' state.

Crucially, parents' belief in the state's orientation towards doing good, was mainly constructed through everyday pedagogic practices of close, warm and often informal collaboration with schools. In coping with the pressures and complexity of the education system, parents generally felt they were working 'hand-in-hand' with teachers (as one mother, Dania, described) - to help their child reach their full potential. Instead of home-school relationships characterised by distance and disenfranchisement (Lareau 2003), parents portrayed their relationships with teachers in positive terms, emphasising teachers' nurturing attitudes towards students and their frequent communication with parents via phone calls and WhatsApp. As some parents worked shift hours, making attendance at parent-teacher meetings difficult, they appreciated teachers updating them in these ways. Communication between parents and teachers was, for at least two families, two-way - parents would update teachers on difficulties at home or in their children's personal lives that they felt teachers should know about (e.g. divorce and school bullying), while teachers provided parents with advice on how their children could study more effectively. Teachers were consulted by parents and young people alike on appropriate post-secondary institutions to attend; parents encouraged their children to seek advice from 'educated teachers' whom they felt, 'know better' than they did - although some families 
saw the collaboration as more equal, with families and schools both required to help young people develop holistically.

Notably, while critical of the stress in Singapore's education system, families collaborated with schools to monitor children, and if necessary, punish them. While young people were responsibilised (as argued earlier) in adult-like ways to bear responsibility for their success and failure, they were also viewed as requiring surveillance by the seemingly true 'adults'. For example, one mother, Hannah, shared:

I think sometimes it's the influence from the friends...[my son] started to do the funny things, so the teacher spoke to me. I really whack him. And then the teacher told me yesterday, 'Hey, really, after I complained to you, he really improved in his studies, he really focuses now.' I said, 'Yeah it's a good thing you tell me earlier, rather than too late!' So, if let's say, the teacher gives feedback earlier, so, we can also can take action.

In the case of most parents, collaboration with schools also helped to compensate for their perceived inadequacies as relatively less-educated parents. Parents drew on another comparative imaginary: their own knowledge and ability, vis-à-vis the state and teachers' knowledge and ability, in a very highlevel and challenging education system. As a low-income group with few credentials valorised within Singapore's financial and cultural systems, it is unsurprising that parents had strong perceptions of their own helplessness, which they connected to their low educational and professional standing.

In spite of the responsibilisation of parents in Singapore, parents simultaneously deeply trusted the state - a trust rooted in an affectively-charged belief in the state's overall orientation towards doing good, rather than harm. This is most clearly seen in families' close, personal relationships with teachers. Teachers were commonly viewed by parents as representatives of the state, particularly as education is viewed as part of the state's benefaction. As teachers were viewed as knowledgeable, professional and caring, parents' positive relationships with teachers reinforced their positive view of, and trust in, the state.

\section{Towards an 'Architecture of Trust'}

This analysis suggests that neoliberalism, trust and responsibilisation simultaneously exist and interrelate in Singapore - though, it seems, not in ways typically conveyed in Anglo-American literature (e.g. Güemes, 2017). We have demonstrated several ways in which the out-workings of these logics in the paternalistic 'strong' state of Singapore are unique to Singapore's socio-political context. In particular, we argue that the co-existence of 'self-responsibilisation' and 'trust' is bridged through an 'architecture of trust'. Moreover, rather than dismissing this 'architecture' as pure 'state-craft', it 
seems sociologically more meaningful to examine the empirical elements that comprise this 'architecture'.

Interview data suggests that the building-blocks of this 'architecture of trust' include: (1) material provision of education and education-related services in a context where parents deeply value qualifications, (2) belief in the efficacy of the Singapore education system (particularly compared to other countries) and in Singaporean meritocracy, (3) friendly, warm relations with school personnel, characterised by close communication and consultation, which powerfully strengthens families' belief in the Singapore state's normative inclination towards doing good, rather than harm.

Although a small-scale study, this research highlights how the dynamics of political trust work in relation to education, amongst low-income families - and underline why the perceived performance of the state and its education system, as well as the ethical orientation of the state towards citizens, are key reasons why families trust the state.

On the one hand, this co-existence of responsibilisation and trust can potentially pry open possibilities for families to optimistically and proactively participate in negotiating better educational and socio-economic opportunities for their children. However, living entirely within an 'architecture of trust' can also normalise the harshness of meritocracy and responsibilisation (particularly of young people), consolidate the ruling party's dominance, and limit the developing of alternative visions of a good life and ways to achieve it. Insofar as an 'architecture of trust' limits critical questioning and the possibility of critical distance from itself, it can exacerbate inequalities, reducing resistance even as middle and upper-class families continue to deploy material resources and cultural capital (Bourdieu, 1986) to leverage their comparative advantage and acquire valorised forms of 'merit'. This analysis suggests that most (though not all) low-income parents generally tend to be unaware of the full extent of the shift from 'meritocracy' to 'parentocracy' precipitated by wealthier families. Moreover, while academic qualifications are viewed as a buffer against future perils - most parents seem unaware of emerging social realities of credential inflation and graduate unemployment. Thus, while political trust can '[oil] the wheels of a variety of...transactions' (Field, 2008:70), it can also lubricate the mechanisms of the affective machinery of 'cruel optimism' (Berlant, 2011).

Finally, this 'architecture' is co-constructed by multiple actors - notably, the 'strong' state, schools, parents and children. As such, the foundations of this 'architecture' - the underpinning power/knowledge relations - warrant interrogation. Notably, are the abovementioned building-blocks under-laid by a foundation of fear of state reprisal, which may have hindered parents from articulating more pointed critiques during interviews? Interview data provides important, yet partial, windows into how fear and trust interrelate. Ultimately, in understanding how 'neoliberalism' is recontextualised (within the Singapore context or elsewhere), the politics of an 'architecture of trust' must be a subject 
of simultaneous study. While this study has elucidated what we view as key aspects of families' pedagogic work, one way future scholarship might mitigate methodological problems related to the politics of expression, is through longer-term ethnographic work to grasp the pervasiveness of dynamics of trust and responsibility.

\section{Conclusion}

Overall, the notion of an 'architecture of trust' charts a way of understanding how low-income parents navigate the coalescence of neoliberal-developmental logics in Singapore's education system. It opens up the possibility that self-responsibilisation can and does co-exist with trust, in the 'strong' neoliberal Singaporean state. However, whether this co-existence continues, and whether this will lead to greater equity, is contingent on whether the Singaporean state can, through its incrasing incorporation of education policy measures towards greater equity (Leonel Lim 2013), provide sufficient support for low-income groups that enable fair competition - and in so doing, deliver on the 'prosperity-loyalty' compact for all Singaporeans. As theorists (e.g. Mishler and Rose, 2001) point out, political trust is closely-wedded to perceptions of effective performance, politically and economically.

While our analysis is specific to the Singapore context, it demonstrates possibilities of how neoliberal practices in a 'strong' state can dynamically interact (in ways often not captured in European-American theorisations), and shape everyday lives. It also highlights the methodological value of foregrounding the perspectives of families as an important prism through which state logics are inflected, and through which we might trace the effects of state logics. As such, families' perspectives, contextualised within the socio-political regime in which they live, remains deeply valuable, in understanding the entanglement of opportunities and constraints embedded in putatively 'successful' Singapore. 
Acknowledgments: The authors gratefully acknowledge the help of the families who participated in this study. This work was financially supported by the Cambridge Trust.

Declaration of Interest: The authors declare that there is no conflict of interest.

\section{References:}

Anderson, Kate T. 2015. "The Discursive Construction of Lower-Tracked Students : Ideologies of Meritocracy and the Politics of Education." Education Policy Analysis Archives 23 (110): 1-30.

Bach, Dil, and Søren Christensen. 2017. "Battling the Tiger Mother: Pre-School Reform and Conflicting Norms of Parenthood in Singapore." Children and Society 31 (2): 134-43.

Barbalet, Jack. 2019. "Trust: Condition of Action or Condition of Appraisal." International Sociology 34 (1): 83-98.

Barr, M., and Z. Skrbis. 2008. Constructing Singapore: Elitism, Ethnicity and the Nation-Building Project. Copenhagen: NIAS Press.

Berlant, Lauren. 2011. Cruel Optimism. USA: Duke University Press.

Blind, Peri K. 2007. "Building Trust in Government in the Twenty-First Century: Review of Literature and Emerging Issues." 7th Global Forum on Reinventing Government Building Trust in Government. 2007.

http://unpan1.un.org/intradoc/groups/public/documents/UN/UNPAN025062.pdf.

Braun, Virginia, and Victoria Clarke. 2006. "Using Thematic Analysis in Psychology." Qualitative Research in Psychology 3 (2): 77-101.

Campbell, Craig, Helen Proctor, and Geoffrey Sherington. 2009. School Choice: How Parents Negotiate the New School Market in Australia. Sydney: Allen and Unwin.

Chua, Beng Huat. 2017. Liberalism Disavowed: Communitarianism and State Capitalism in Singapore. Ithaca \& London: Cornell University Press.

Deng, Zongyi, and Saravanan Gopinathan. 2016. "PISA and High-Performing Education Systems: Explaining Singapore's Education Success." Comparative Education 52 (4): 449-72.

Dimmock, Clive, and Cheng Yong Tan. 2015. "Explaining the Success of the World's Leading Education Systems: The Case of Singapore.” British Journal of Educational Studies, 1-24.

Edelman. 2018. "2018 Edelman Trust Barometer: Global Report.” 2018. https://www.slideshare.net/EdelmanAPAC/2018-edelman-trust-barometer-singapore.

Field, John. 2008. Social Capital. 2nd ed. New York: Routledge.

Flew, Terry. 2014. "Six Theories of Neoliberalism." Thesis Eleven 122 (1): 49-71. https://doi.org/10.1177/0725513614535965.

Foucault, Michel. 1979. Discipline and Punish. USA: Vintage Books.

Gee, Christopher. 2012. “The Educational 'Arms Race': All for One, Loss for All.” 20. Singapore: Institute of Policy Studies.

Gopinathan, Saravanan. 2007. "Globalisation, the Singapore Developmental State and Education Policy: A Thesis Revisited." Globalisation, Societies and Education 5 (1): 53-70. https://doi.org/10.1080/14767720601133405.

_ 2012. "Are We All Global Citizens Now? Reflections on Citizenship and Citizenship Education in a Globalising World (With Special Reference to Singapore)." Hong Kong: Centre for Governance and Citizenship, The Hong Kong Institute of Education.

Güemes, Cecilia. 2017. "Neoliberal Welfare Policy Reforms and Trust: Connecting the Dots." Journal of Iberian and Latin American Research 23 (1): 18-33. https://doi.org/10.1080/13260219.2017.1298825.

Hetherington, Marc J. 1998. "The Political Relevance of Political Trust." The American Political Science Review 92 (4): 791-808.

Ho, Peter. 2018. "The Evolution of Public Trust in Singapore and the Impact of Technology." In 
Public Trust in Singapore, edited by David Chan. Singapore: World Scientific.

Khong, Lana Yiu Lan, and Pak Tee Ng. 2005. "School-Parent Partnerships in Singapore."

Educational Research for Policy and Practice 4 (1): 1-11.

Koh, Aaron. 2014. "Doing Class Analysis in Singapore's Elite Education: Unravelling the

Smokescreen of 'Meritocratic Talk."' Globalisation, Societies and Education 12 (2): 196-210.

Lareau, Annette. 2003. Unequal Childhoods: Class, Race and Family Life. USA: University of California Press.

Levi, Margaret, and Laura Stoker. 2000. "Political Trust and Trustworthiness." Annual Review of Political Science 3: 475-507.

Lim, L. 2016. "Globalization, the Strong State and Education Policy: The Politics of Policy in Asia." Journal of Education Policy 31 (6): 711-26.

Lim, Leonel. 2013. "Meritocracy, Elitism, and Egalitarianism: A Preliminary and Provisional Assessment of Singapore's Primary Education Review." Asia Pacific Journal of Education 33 (1): 1-14. https://doi.org/10.1080/02188791.2012.711294.

Lim, Leonel, and Michael W. Apple. 2016. "Introducing the Strong State and Curriculum Reform in Asia." In The Strong State and Curriculum Reform: Assessing the Politics and Possibilities of Educational Change in Asia, edited by Leonel Lim and Michael Apple, 1-20. Abingdon: Routledge.

Liow, Eugene Dili. 2011. "The Neoliberal-Developmental State: Singapore as Case Study." Critical Sociology 38 (2): 241-64.

Mishler, William, and Richard Rose. 2001. "What Are the Origins of Political Trust? : Testing Institutional and Cultural Theories in Post-Communist Societies" 34 (1): 30-62.

Misztal, Barbara A. 1996. Trust in Modern Societies. USA: Blackwell Publishers.

Moore, R. Quinn. 2000. "Multiracialism and Meritocracy: Singapore's Approach to Race and Inequality." Review of Social Economy 58 (3): 339-60.

Ng, Irene Y.H. 2014. "Education and Intergenerational Mobility in Singapore." Educational Review 66 (3): 362-76. https://doi.org/10.1080/00131911.2013.780008.

Ong, Aihwa. 2007. "Boundary Crossings: Neoliberalism as a Mobile Technology." Transaction of the Institute of British Geographers 32: 3-8. https://doi.org/10.1111/j.1475-5661.2007.00234.x.

Ong, Andrea. 2014. "Beware Growing 'Parentocracy': NIE Don.” The Straits Times, March 30, 2014. https://www.straitstimes.com/singapore/beware-growing-parentocracy-nie-don.

Rodan, Garry. 2016. "Capitalism, Inequality and Ideology in Singapore: New Challenges for the Ruling Party." Asian Studies Review 40 (2): 211-30. https://doi.org/10.1080/10357823.2016.1155536.

Senin, Nursila, and Irene Y.H. Ng. 2012. "Educational Aspirations of Malay Youths from LowIncome Families in Singapore." Asia Pacific Journal of Social Work and Development 22 (4): 253-65.

Shamir, Ronen. 2008. "The Age of Responsibilization: On Market-Embedded Morality.” Economy and Society 37 (1): 1-19. https://doi.org/10.1080/03085140701760833.

Singapore Department of Statistics. 2016. “General Household Survey 2015.” 2016. https://www.singstat.gov.sg/publications/ghs/ghs2015.

Talib, Nadira, and Richard Fitzgerald. 2015. "Inequality As Meritocracy." Critical Discourse Studies 12 (4): 445-62.

Tan, Charlene. 2019. "Parental Responses to Education Reform in Singapore, Shanghai and Hong Kong." Asia Pacific Education Review 20 (1). https://doi.org/10.1007/s12564-018-9571-4.

Tan, Ern Ser. 2004. Does Class Matter: Social Stratification and Orientations in Singapore. Singapore: World Scientific.

Tan, Kenneth Paul. 2008. "Meritocracy and Elitism in a Global City: Ideological Shifts in Singapore." International Political Science Review 29 (1): 7-27.

https://doi.org/10.1177/0192512107083445. 
Tao, Ran, Dali L. Yang, Ming Li, and Xi Lu. 2014. "How Does Political Trust Affect Social Trust? An Analysis of Survey Data from Rural China Using an Instrumental Variables Approach." International Political Science Review 35 (2): 237-53. https://doi.org/10.1177/0192512113492599.

Teo, Youyenn. 2013. "Support for Deserving Families: Inventing the Anti-Welfare Familialist State in Singapore." Social Politics 20 (3): 387-406.

- 2018. This Is What Inequality Looks Like. Singapore: Ethos Books.

Ule, Mirjana, Andreja Živoder, and Manuela du Bois-Reymond. 2015. “'Simply the Best for My Children': Patterns of Parental Involvement in Education." International Journal of Qualitative Studies in Education 28 (3): 329-48.

Vincent, Carol, and Stephen J. Ball. 2007. “'Making up' the Middle-Class Child: Families, Activities and Class Dispositions." Sociology 41 (6): 1061-77. https://doi.org/10.1177/0038038507082315.

Vincent, Carol, and Claire Maxwell. 2016. "Parenting Priorities and Pressures: Furthering Understanding of 'Concerted Cultivation."” Discourse 37 (2): 269-81. https://doi.org/10.1080/01596306.2015.1014880.

Wang, Zhengxu. 2005. "Before the Emergence of Critical Citizens: Economic Development and Political Trust in China." International Review of Sociology 15 (1): 155-71. https://doi.org/10.1080/03906700500038876.

Watkins, Megan, and Greg Noble. 2013. Disposed to Learn: Schooling, Ethnicity and the Scholarly Habitus. London: Bloomsbury.

Wong, Timothy Ka-ying, Po-san Wan, and Michael Hsiao. 2011. "The Bases of Political Trust in Six Asian Societies: Institutional and Cultural Explanations Compared." International Political Science Review 32 (3): 263-81. https://doi.org/10.1177/0192512110378657. 